\title{
PERAN SEMANGAT KERJA MEMEDIASI PENGARUH LINGKUNGAN KERJA TERHADAP KINERJA PEGAWAI DINAS KESEHATAN KABUPATEN TABANAN, BALI
}

\author{
Ni Made Dewi Kansa Putri \\ Manajemen Informatika STMIK STIKOM Bali \\ email : kansa@stikom-bali.ac.id
}

\begin{abstract}
ABSTRAK
The government to provide the excellent public service performance must supported by existing resources. Human factors or man power are an important part of an organization, where talented, qualified human resources are needed, willing to cooperate with teams and have high spirit. Work spirit is needed in every employee cooperation effort to achieve organizational goals, because with the work spirit will result in high performance for the organization. Besides that, employee performance is also determined by the work environment both physical and non-physical. This study aims to analyze the influence of the work environment and work spirit on the performance of employees at the Tabanan District Health Office. Research uses Path Analysis as a method of data analysis, where data collection is done by observation, interviews, literature studies, and questionnaires. As the initial stage of the analysis, a validity and reliability test will be carried out on the research instrument. The results showed that the work environment and work spirit had a positive and significant effect on employee performance at the Tabanan District Health Office. Where the work spirit variable acts as an mediation variable in the influence of the work environment on employee performance at the Tabanan District Health Office.
\end{abstract}

Kata kunci: work environment, work spirit, employee performance

\section{PENDAHULUAN}

Pengembangan sistem penyelenggaraan pemerintahan yang terukur dan legitimate merupakan sebuah syarat terwujudnya penyelenggaraan pemerintahan yang baik (Good Governance). Pemerintah sebagai suatu organisasi dalam menampilkan kinerja pelayanan publik yang prima tentu saja harus didukung oleh sumber daya yang ada. Salah satu sumber daya yang penting dalam organisasi yang sangat berarti dalam menopang keberhasilan mencapai tujuan adalah sumber daya manusia. Tujuan organisasi akan dapat dicapai melalui kinerja yang positif dari pegawainya, sebaliknya organisasi akan 
menghadapi hambatan dalam mencapai tujuan jika kinerja para pegawai tidak efektif, dalam arti tidak dapat memenuhi tuntutan pekerjaan yang diinginkan oleh organisasi.

Kinerja merupakan faktor sentral bagi pekerjaan manajemen dalam mengelola organisasi, maka dari itu bagi pimpinan organisasi, kinerja pegawai menjadi sangat penting karena ia merupakan tolak ukur bagi keberhasilan dalam mengelola organisasi yang dipimpinnya. Suatu organisasi, dibutuhkan semangat kerja yang tinggi untuk menciptakan kinerja yang baik. Menurut Sastrohadiwiryo (2008:30) semangat kerja yang tinggi sangat diperlukan dalam setiap usaha kerjasama pegawai untuk mencapai tujuan organisasi, sebab dengan adanya semangat kerja yang tinggi akan menghasilkan kinerja dan produktivitas yang tinggi bagi organisasi.

Pegawai mempunyai semangat kerja yang tinggi, apabila pegawai tampak merasa senang, optimis mengenai kegiatan dan tugas, serta ramah satu sama lain. Sebaliknya, apabila pegawai tampak tidak puas, lekas marah, sering sakit, suka membantah, gelisah, dan pesimis, maka reaksi ini dikatakan sebagai bukti semangat kerja yang rendah. Jadi dapat diartikan bahwa semangat kerja adalah sikap individu ataupun sekelompok orang terhadap kesukarelaannya untuk bekerjasama agar dapat mencurahkan kemampuannya secara menyeluruh. Semangat kerja sangat dibutuhkan agar suatu pekerjaan itu dapat terlihat maksimal.

Selain faktor semangat kerja, faktor lainnya yang mempengaruhi kinerja pegawai adalah faktor lingkungan kerja. Tohardi (2002:137) menyatakan bahwa yang termasuk lingkungan kerja fisik adalah ruangan, suhu ruangan, gangguan suara dalam ruangan, dan fasilitas kerjanya. Kondisi lingkungan kerja yang baik ditandai oleh penerangan yang cukup dan dipancarkan secara mereta serta jauh dari kebisingan yang mengganggu konsentrasi kerja, tata ruang yang baik dan warna yang indah, serta kebersihan yang 
terjaga, sangat membuat karyawan betah bekerja. Disamping lingkungan kerja fisik, lingkungan kerja non fisik juga memberikan pengaruh berati dalam menciptakan semangat dan kinerja karyawan. Lingkungan kerja non fisik mencakup hubungan antara atasan dengan bawahan, bawahan dengan rekan kerjanya di dalam organisasi. Semakin baik lingkungan kerja non fisik yang tercipta dalam hal ini keharmonisan hubungan kerja yang terjalin dalam organisasi akan mendorong semangat pegawai dalam bekerja yang pada akhirnya meningkatkan kinerja pegawai secara keseluruhan.

Dinas Kesehatan Kabupaten Tabanan sebagai salah satu instansi milik pemerintah yang melayani masyarakat dalam bidang kesehatan, sangat perlu memperhatikan dan membina kinerja pegawainya. Sesuai dengan visi Dinas Kesehatan Kabupaten Tabanan yaitu "Terwujudnya Masyarakat Tabanan Sehat Melalui Suatu Sistem Pelayanan Kesehatan Yang Baku, Terstandar dan Fleksibel Melalui Reformasi Bidang Kesehatan Secara Bertahap.” Guna terwujudkan visi tersebut tentunya pegawai Dinas Kesehatan Kabupaten Tabanan dituntut memberikan kinerja yang baik dalam rangka memberikan pelayanan kepada masyarakat.

Berdasarkan hasil observasi dan wawancara, terdapat beberapa target program yang belum tercapai, seperti cakupan pelayanan kesehatan masyarakat miskin. Target di tahun 2017 adalah 100\%, sedangkan realisasinya adalah 67,68\%. Hal tersebut terjadi karena cakupan pelayanan kesehatan masyarakat miskin di kota Tabanan dihitung berdasarkan persentase jumlah kunjungan masyarakat miskin di sarana kesehatan strata 1 yang dibagi jumlah seluruh masyarakat miskin di Kota Tabanan. Belum tercapainya target yang diharapkan pada tahun 2017 menunjukkan bahwa kinerja pegawai juga belum optimal. Seluruh pimpinan dan staf Dinas Kesehatan Kabupaten Tabanan mempunyai komitmen untuk memberikan pelayanan secara baik dan maksimal kepada masyarakat, 
sehingga dapat mengantisipasi tugas-tugas tersebut. Diperlukan adanya semangat kerja pegawai yang tinggi, agar dapat memberikan pelayanan yang memuaskan kepada masyarakat.

Sumber daya manusia yang baik akan membantu organisasi mencapai tujuan yang telah direncanakan dengan cepat. Peran lingkungan kerja di Dinas Kesehatan Kabupaten Tabanan akan dapat berpengaruh pada pegawai untuk meningkatkan semangat kerja sehingga kinerja yang dihasilkan akan tercapai maksimal. Oleh karena itu, faktor lingkungan kerja dan semangat kerja akan menjadi faktor yang dapat menjadikan seseorang pegawai dapat meningkatkan kinerja yang berarti pada organisasi.

Berdasarkan latar belakang masalah tersebut, adapun tujuan penelitian ini adalah: 1) Untuk mengetahui pengaruh lingkungan kerja terhadap semangat kerja pegawai Dinas Kesehatan Kabupaten Tabanan, 2) Untuk mengetahui pengaruh lingkungan kerja terhadap kinerja pegawai Dinas Kesehatan Kabupaten Tabanan, 3) Untuk mengetahui pengaruh semangat kerja terhadap kinerja pegawai Dinas Kesehatan Kabupaten Tabanan, 4) Untuk mengetahui peran semangat kerja sebagai variabel intervening pada pengaruh lingkungan terhadap kinerja pegawai Dinas Kesehatan Kabupaten Tabanan.

Terdapat sejumlah kajian teoritik yang digunakan dimana relevan dengan variabel yang dibahas dalam penelitian ini, sebagai berikut:

\section{Kinerja Pegawai}

Kinerja dalam organisasi merupakan jawaban dari berhasil atau tidaknya tujuan organisasi yang telah ditetapkan. Suatu organisasi selalu digerakkan oleh sekelompok orang yang berperan aktif untuk mencapai tujuan yang ingin dicapai dari organisasi tersebut. Tujuan organisasi tentunya tidak akan tercapai jika kinerja pegawainya tidak maksimal. Kinerja atau performance adalah hasil kerja yang dapat dicapai oleh seseorang 
atau sekelompok orang dalam suatu organisasi, sesuai dengan wewenang dan tanggung jawab masing-masing, dalam rangka upaya mencapai tujuan organisasi bersangkutan secara legal, tidak melanggar hukum dan sesuai dengan moral maupun etika.

Kinerja pegawai (prestasi kerja) adalah hasil kerja secara kualitas dan kuantitas yang dicapai oleh seseorang pegawai dalam melaksanakan tugasnya sesuai dengan tanggung jawab yang diberikan kepadanya (Mangkunegara, 2005:9). Berbagai pendapat diatas dapat menggambarkan bahwa kinerja pegawai dan kinerja organisasi memiliki keterkaitan yang sangat erat, tercapainya tujuan organisasi tidak bisa dilepaskan dari sumber daya yang dimiliki oleh organisasi yang digerakkan atau dijalankan pegawai yang berperan aktif sebagai pelaku dalam upaya mencapai tujuan organisasi. Jadi dapat dinyatakan bahwa kinerja pegawai adalah penilaian hasil kerja seseorang dalam suatu organisasi dengan tugas dan tanggung jawabnya dalam rangka mencapai tujuan organisasi.

\section{Semangat Kerja}

Semangat kerja atau dalam istilah asingnya disebut morale merupakan hal yang harus dimiliki oleh setiap pegawai agar produktivitas kerjanya meningkat, oleh karena itu selayaknya setiap instansi selalu berusaha agar semangat kerja pegawai meningkat. Dengan semangat kerja yang tinggi, maka dapat di harapkan aktivitas instansi dapat berjalan dengan baik sehingga tujuan instansi dapat tercapai. Berikut pengertian semangat kerja yang dikemukakan oleh para ahli di antaranya adalah :

Menurut Nitisemito (2001:160), semangat kerja adalah melakukan pekerjaan dengan lebih giat sehingga dengan demikian pekerjaan dapat selesai lebih cepat dan lebih baik, lebih lanjut dapat diartikan semangat kerja sebagai sesuatu yang positif dan sesuatu baik, 
sehingga mampu memberikan sumbangan terhadap pekerjaan dalam arti lebih cepat dan lebih baik.

Menurut Siswanto (2001:264), semangat kerja adalah sebagai suatu kondisi rohaniah atau perilaku individu tenaga kerja dan kelompok-kelompok yang menimbulkan kesenangan dalam diri pekerja untuk bekerja dengan giat dan berkonsekuensi dalam mencapai tujuan dan aturan niat yang telah di tetapkan oleh instansi. Menurut Hasibuan (2008:95), mengemukakan bahwa semangat kerja adalah sebagai keinginan dan kesungguhan seseorang mengerjakan pekerjaan dengan baik serta berdisiplin untuk mencapai hasil yang maksimal.

Berdasarkan pengertian para ahli dapat dinyatakan bahwa semangat kerja adalah suatu ekspresi dan mental individu atau kelompok yang menunjukan rasa senang dan bahagia dalam melakukan pekerjaannya, sehingga merasa dan mampu bekerja secara lebih dan lebih baik demi tercapainya tujuan instansi.

\section{Lingkungan Kerja}

Lingkungan kerja yang baik akan membuat pegawai bekerja pada kondisi yang menyenangkan atau bersemangat dan akan menyebabkan pekerjaan dapat terselesaikan secara memuaskan dan tepat pada waktunya. Lingkungan kerja yang menyenangkan akan menjadi dambaan bagi seluruh karyawan yang ada dalam sebuah perusahaan atau organisasi.

Nitisemito (2001:183) mendefinisikan lingkungan kerja adalah segala sesuatu yang ada dilingkungan sekitar para pekerja dan yang dapat mempengaruhi dirinya dalam menjalankan tugas - tugas yang dibebankan kepadanya. Lingkungan kerja berkaitan dengan lingkungan kerja secara fisik maupun lingkungan kerja non fisik. Lingkungan kerja fisik berkaitan dengan keseluruhan sarana dan prasarana yang ada disekitar karyawan 
seperti: kondisi ruangan kerja, dan fasilitas kerja yang dapat mempengaruhi semangat kerja karyawan dalam menjalankan tugas - tugas yang dibebankan padanya. Sementara lingkungan kerja non fisik akan berkaitan dengan hubungan kerjasama atau relasi yang melibatkan atasan dengan bawahan maupun rekan kerja. Hubungan relasi tersebut nantinya akan berpengaruh pada komunikasi dan kerjasama dalam organisasi dimana karyawan tersebut bekerja.

Berdasarkan kajian teoritik dan penelitian sebelumnya yang dijadikan bahan referensi dalam penelitian ini, dirumuskan hipotesis dalam penelitian ini sebagai berikut:

H1 Diduga ada pengaruh signifikan lingkungan kerja dengan semangat kerja pegawai pada Dinas Kesehatan Kabupaten Tabanan.

H2 Diduga ada pengaruh signifikan lingkungan kerja dengan kinerja pegawai pada Dinas Kesehatan Kabupaten Tabanan

H3 Diduga ada pengaruh signifikan semangat kerja dengan kinerja pegawai pada Dinas Kesehatan Kabupaten Tabanan.

H4 Diduga semangat kerja berperan memediasi pengaruh lingkungan kerja terhadap kinerja pegawai di Dinas Kesehatan Kabupaten Tabanan.

Penelitian ini nantinya memberikan kontribusi bagi upaya peningkatan kinerja pegawai pemerintahan khususnya pada Dinas Kesehatan di Kabupaten Tabanan, Bali, sehingga akan lebih optimal dalam memberikan pelayanan kepada masyarakat luas. Selain itu, penelitian ini dapat dijadikan tambahan referensi dan kajian berkaitan dengan faktor faktor yang mempengaruhi kinerja karyawan sebagai bagian dari pengelolaan sumber daya manusia.

\section{METODOLOGI PENELITIAN}

\section{Desain Penelitian}


Kinerja merupakan faktor sentral bagi pekerjaan manajemen dalam mengelola organisasi, maka dari itu bagi pimpinan organisasi, kinerja pegawai menjadi sangat penting karena ia merupakan tolak ukur bagi keberhasilan dalam mengelola organisasi yang dipimpinnya. Suatu organisasi, membutuhkan semangat kerja yang tinggi untuk menciptakan kinerja yang baik. Selain semangat kerja untuk meningkatkan kinerja pegawai faktor lingkungan kerja memegang peranan yang penting karena lingkungan kerja yang baik dan kondusif akan membuat pegawai nyaman dan semangat dalam mengerjakan tugas - tugas yang dibebankan kepada mereka. Berdasarkan uraian tersebut, maka dapat disusun skematis kerangka konsep penelitian.

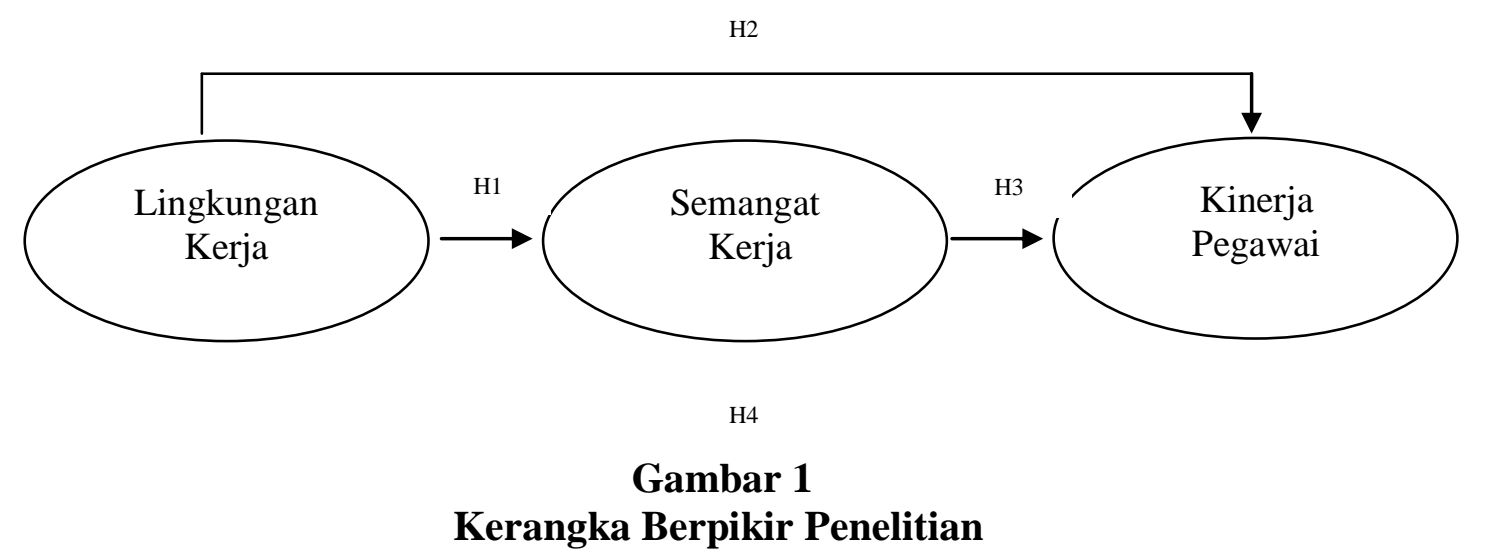

\section{Identifikasi Variabel}

1. Variabel Bebas (Independen)

Dalam penelitian ini yang menjadi variabel bebas adalah lingkungan kerja, dimana diukur dengan indikator: penerangan, sirkulasi udara, kebisingan, bau tak sedap, keamanan, hubungan dengan rekan kerja, hubungan dengan pimpinan,

2. Variabel Terikat (Dependen) 
Dalam penelitian ini yang menjadi variabel bebas adalah kinerja pegawai, dimana diukur dengan indikator: orientasi pelayanan, integritas, komitmen, disiplin, kerjasama, dan kepemimpinan.

3. Variabel Intervening

Dalam penelitian ini yang menjadi variabel intervening adalah semangat kerja yang diukur dengan indikator: minat menuntaskan pekerjaan, penghargaan pekerjaan berupa gaji, peningkatan status sosial, dan dukungan lingkungan kerja.

Pengukuran data menggunakan skala likert dengan kriteria skor sebagai berikut: Sangat Setuju (5), Setuju (4), Ragu - Ragu (3), Tidak Setuju (2), dan Sangat Tidak Setuju (1).

\section{Populasi dan Sampel}

Populasi dalam penelitian ini adalah jumlah pegawai pada Dinas Kesehatan Kabupaten Tabanan yang berjumlah 147 orang, dengan rincian Pegawai Negeri Sipil sebanyak 75 orang, pegawai kontrak sebanyak 72 orang, tidak termasuk kepala dinas dan sekretaris. Pengambilan sampel dalam penelitian ini dengan teknik probability sampling yaitu proportionate stratified random sampling dengan menggunakan rumus slovin. Menurut Sugiyono (2010:63), Probability sampling adalah teknik pengambilan sampel yang memberikan peluang yang sama bagi setiap unsur (anggota) populasi untuk dipilih menjadi anggota sampel.

Besarnya sampel dalam penelitian ini ditentukan dengan rumus Solvin sebagai berikut :

$$
n=\frac{N}{1+N e^{2}}
$$

Dimana :

$\mathrm{n} \quad=$ Jumlah elemen / anggota sampel

$\mathrm{N}$ = Jumlah elemen / anggota populasi 
$\mathrm{e} \quad=$ Error level (tingkat kesalahan)

Populasi yang terdapat dalam penelitian ini berjumlah 147 orang dan presisi yang ditetapkan atau tingkat signifikansi 0,05, maka besarnya sampel pada penelitian ini adalah:

$n=\frac{\mathrm{N}}{1+\left(\mathrm{N} \cdot \mathrm{e}^{2}\right)}$

$$
\begin{aligned}
n & =\frac{147}{1+147 \cdot 0,05^{2}} \\
& =107,495 \text { dibulatkan menjadi } 107
\end{aligned}
$$

Jadi, jumlah keseluruhan responden dalam penelitian ini adalah 107 orang.

\section{Teknik Analisis Data}

1. Pengujian Instrumen Penelitian

Pengujian instrument penelitian menggunakan uji validitas dan uji reliabilitas. Uji validitas digunakan untuk mengukur sah atau valid tidaknya suatu kuesioner. Suatu kuesioner dikatakan valid jika pertanyaan pada kuesioner mampu mengungkapkan sesuatu yang akan diukur oleh kuesioner tersebut. Sedangkan reliabilitas adalah alat untuk mengukur suatu kuesioner yang merupakan indikator dari variabel. Suatu kuesioner dikatakan reliable atau handal jika jawaban seseorang terhadap pernyataan adalah konsisten atau stabil dari waktu ke waktu (Sugiyono, 2011).

2. Analisis Jalur

Analisis jalur (path analysis) merupakan aplikasi khusus dengan dasar analisis regresi dan korelasi yang digunakan menganalisis pola hubungan antar variabel dengan tujuan mengetahui pengaruh langsung maupun tidak langsung dari variabel bebas (Independen) terhadap variabel terikat (Dependen). Dalam penelitian ini menggunakan 
1 (satu) variabel Independen, 1 (satu) variabel Dependen, dan 1 (satu) variabel Intervening, sehingga persamaan analisis jalur adalah sebagai berikut:

Sub Struktur 1:

$\mathrm{Y}_{1}=\beta_{1} \mathrm{X}+\mathrm{e}$

Sub Struktur 2:

$\mathrm{Y}_{2}=\beta_{1} \mathrm{X}+\beta_{2} \mathrm{M}+\mathrm{e}$

Keterangan:

$\mathrm{X}=$ Variabel Independen (Lingkungan Kerja)

Y1 = Intervening $($ Semangat Kerja $)$

Y2 = Dependent $($ Kinerja $)$

$\mathrm{e}=$ nilai residu

\section{HASIL DAN PEMBAHASAN}

\section{Uji Instrumen Penelitian}

Hasil uji validitas menunjukkan bahwa nilai rhitung (Corrected Item - Total Correlation) untuk semua item pernyataan $\geq 0,30$. Oleh karena itu instrumen pengukuran yang digunakan dalam penelitian ini dinyatakan valid. Hasil uji reliabilitas menunjukkan bahwa nilai Cronbach's Alpha untuk semua variabel $\geq 0,70$. Oleh karena itu instrumen pengukuran yang digunakan dalam penelitian ini dinyatakan reliable.

\section{Analisis Jalur}

Berdasarkan hasil pengolahan data regresi, dapat diringkas koefisien jalur sebagai yang ditampilkan pada Tabel 1 berikut ini.

Tabel 1. Ringkasan Koefisien Jalur

$\begin{array}{cccccc}\text { Hubungan } & \begin{array}{c}\text { Unstandardized } \\ \text { Coefficients }\end{array} & \begin{array}{c}\text { Standardized } \\ \text { Coefficients }\end{array} & \begin{array}{c}\text { Standard } \\ \text { Error }\end{array} & \text { thitung } & \text { P.Value }\end{array}$ Keterangan




\begin{tabular}{lllllll}
\hline $\mathbf{X} \square \mathbf{M}(\mathbf{b} 1)$ & 0,369 & 0,729 & 0,034 & 10,913 & 0,000 & Signifikan \\
$\mathbf{X} \square \mathbf{Y}(\mathbf{b 2})$ & 0,361 & 0,469 & 0,081 & 4,440 & 0,000 & Signifikan \\
$\mathbf{M} \square \mathbf{Y}$ (b3) & 0,385 & 0,254 & 0,160 & 2,402 & 0,018 & Signifikan \\
\hline
\end{tabular}

Keterangan: X (Lingkungan Kerja), M (Semangat Kerja), Y (Kinerja)

Berdasarkan Tabel 1 dapat dijelaskan bahwa seluruh variabel berpengaruh positif. Lingkungan kerja berpengaruh positif terhadap semangat kerja dan kinerja pegawai.Begitu juga untuk variabel semangat kerja, juga dapat berpengaruh positif terhadap kinerja pegawai. Berdasarkan ringkasan koefisien jalur pada Tabel 1 dapat dibuat gambar sebagai berikut.

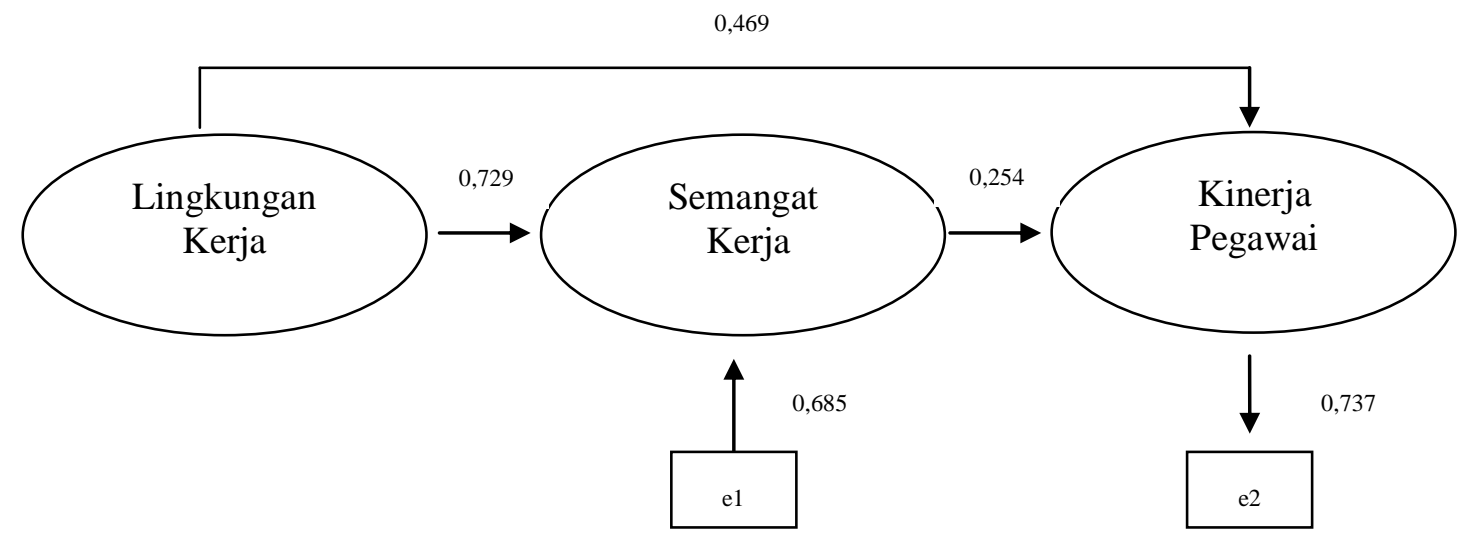

Gambar 2

Koefisien Jalur Lingkungan Kerja, Semangat Kerja, dan Kinerja Pegawai

Persamaan struktural untuk model tersebut adalah:

Model persamaan 1: $\mathrm{M}=0,729 \mathrm{X}+\mathrm{e} 1$

Model persamaan 2: $\mathrm{Y}=0,469 \mathrm{X}+0,254 \mathrm{M}+\mathrm{e} 2$

Koefisien pada Gambar 2 merupakan koefisien hubungan langsung antarvariabel. Berdasarkan Gambar tersebut dapat dihitung hubungan langsung, tidak langsung dan total seperti Tabel 2. 
Tabel 2. Koefisien Hubungan Langsung, Tidak Langsung, dan Total Antarvariabel

\begin{tabular}{cccc}
\hline Pengaruh & Langsung (Direct) & Tidak Langsung (Indirect) & Total Effect \\
\hline $\mathbf{X} \square \mathbf{M ~ X} \square$ & 0,729 & 0,000 & 0,729 \\
$\mathbf{Y}$ & 0,469 & 0,185 & 0,654 \\
$\mathbf{M} \square \mathbf{Y}$ & 0,254 & 0,000 & 0,254 \\
\hline
\end{tabular}

Keterangan: X (Lingkungan Kerja), M (Semangat Kerja), Y (Kinerja)

\section{Pengujian Hipotesis}

Pengujian hipotesis menunjukkan seberapa jauh pengaruh satu variabel bebas secara individual dalam menerangkan variasi variabel terikat. Berdasarkan hasil pengolahan data, maka berikut pengujian hipotesis penelitian.

1. Pengaruh Lingkungan Kerja terhadap Semangat Kerja Pegawai pada Dinas Kesehatan Kabupaten Tabanan

Berdasarkan hasil pengujian menunjukkan bahwa koefisien regresi dari lingkungan kerja terhadap semangat kerja adalah sebesar 0,729 dengan taraf signifikansi $0,000<$ 0,050. Hasil tersebut menyatakan bahwa lingkungan kerja berpengaruh positif dan signifikan pada semangat kerja pegawai, sehingga penelitian ini menerima hipotesis 1. Lingkungan kerja baik itu lingkungan kerja fisik maupun non fisik memiliki peranan yang sangat penting dalam mendorong semangat kerja pegawai. Lingkungan kerja fisik yang nyaman, aman, dan tertata dengan baik akan meningkatkan giat atau semangat pegawai dalam bekerja. Demikian halnya pula pada lingkungan kerja non fisik yang menekankan hubungan kerjasama antara pegawai dengan pimpinan maupun rekan kerjanya, dimana semakin baik hubungan kerjasama yang terjalin maka akan mendorong semangat kerja pegawai tersebut.

2. Pengaruh Lingkungan Kerja terhadap Kinerja Pegawai pada Dinas Kesehatan Kabupaten Tabanan 
Berdasarkan hasil pengujian menunjukkan bahwa koefisien regresi dari lingkungan kerja terhadap kinerja pegawai adalah sebesar 0,469 dengan taraf signifikansi $0,000<0,050$. Hasil tersebut menyatakan bahwa lingkungan kerja berpengaruh positif dan signifikan pada kinerja pegawai, sehingga penelitian ini menerima hipotesis 2 . Lingkungan kerja yang baik akan mendukung pencapaian kinerja pegawai yang optimal, dimana semakin baik dan kondusifnya lingkungan kerja akan meningkatkan kinerja pegawai tersebut.

3. Pengaruh Semangat Kerja terhadap Kinerja Pegawai pada Dinas Kesehatan Kabupaten Tabanan

Berdasarkan hasil pengujian menunjukkan bahwa koefisien regresi dari semangat kerja pada kinerja pegawai adalah sebesar 0,254 dengan taraf signifikansi $0,018<0,050$. Hasil tersebut menyatakan bahwa semangat kerja berpengaruh positif dan signifikan pada kinerja pegawai, sehingga penelitian ini menerima hipotesis 3 . Pegawai yang memiliki semangat kerja yang tinggi akan menghasilkan pencapaian kinerja pegawai yang optimal pula. Dimana pencapaian kinerja yang optimal ini akan memungkinkan tercapainya tujuan organisasi atau perusahaan tersebut.

4. Peran Mediasi Semangat Kerja pada Pengaruh Lingkungan Kerja terhadap Kinerja Pegawai pada Dinas Kesehatan Kabupaten Tabanan

Berdasarkan hasil pengujian menunjukkan bahwa nilai signifikasi dari semangat kerja berdasarkan tes sobel dan uji residual adalah masing-masing sebesar 0,010 dan 0,003 $<0,050$. Hasil tersebut menyatakan bahwa semangat kerja merupakan variabel mediasi sehingga hipotesis 4 dalam penelitian ini diterima. Pegawai yang merasakan lingkungan kerja yang nyaman, aman, dan kondusif akan semakin menunjukkan semangatnya dalam bekerja, dimana dorongan semangat kerja tersebut nantinya akan 
meningkatkan pencapaian kinerja pegawai yang semakin baik, sehingga pada akhirnya dapat meningkatkan pencapaian tujuan organisasi secara keseluruhan.

\section{SIMPULAN DAN SARAN}

Berdasarkan hasil pembahasan penelitian dapat disimpulkan sebagai berikut:

1. Lingkungan kerja berpengaruh positif dan signifikan terhadap semangat kerja pegawai pada Dinas Kesehatan Kabupaten Tabanan.

2. Lingkungan kerja berpengaruh positif dan signifikan terhadap kinerja pegawai pada Dinas Kesehatan Kabupaten Tabanan.

3. Semangat kerja berpengaruh positif dan signifikan terhadap kinerja pegawai pada Dinas Kesehatan Kabupaten Tabanan.

4. Semangat kerja berperan memediasi pengaruh lingkungan kerja terhadap kinerja pegawai pada Dinas Kesehatan Kabupaten Tabanan.

Saran - saran yang dapat dikemukakan dalam penelitian ini yaitu:

1. Hasil penelitian menunjukkan bahwa lingkungan kerja dan semangat kerja pegawai berpengaruh positif dan signifikan terhadap kinerja pegawai, maka sebaiknya pimpinan Dinas Kesehatan Kabupaten Tabanan lebih memperhatikan kenyamanan lingkungan kerja baik fisik maupun non fisik serta senantiasa mendorong semangat kerja pegawai sehingga dapat mencapai kinerja pegawai yang diharapkan dapat mencapai tujuan organisasi.

2. Hasil penelitian ini dapat digunakan peneliti berikutnya untuk menambahkan variabel lainnya terkait dengan kinerja pegawai seperti variabel kompensasi, kepuasan kerja, maupun budaya organisasi. 


\section{DAFTAR PUSTAKA}

Alex Soemadji Nitosemito. 2001. Manajemen Personalia. Jakarta: Ghalia Indonesia

Alex Soemadji Nitosemito. 2005. Manajemen Personalia (Manajemen Sumber Daya Manusia). Edisi Kelima. Cetakan Keempat belas. Ghalia Indonesia

A.M, Kadarman, dan Jusuf Udaya, dkk. 2001. Pengantar Ilmu Manajemen. Jakarta: PT. Prehallindo

Azwar, Saifuddin. 2002. Sikap Manusia, Teori dan Pengukurannya. Yogyakarta: Pustaka Pelajar

Ghozali, Imam. 2011. Aplikasi Analisis Multivariate Dengan Program SPSS. Semarang : Badan Penerbit Universitas Diponegoro.

Gorda. 2004. Manajemen Sumber Daya Manusia. Denpasar : Widya Kriya Gematama

Hasibuan. Melayu S.P. 2006. Manajemen Dasar, Pengertian, dan Masalah, Edisi Revisi. Bumi Aksara:Jakarta

Hasibuan. Melayu S.P. 2008. Manajemen Sumber Daya Manusia. Jakarta: PT. Bumi Aksara

Mangkunegara. 2005. Sumber Daya Manusia Perusahaan. Remaa Rosdakarya: Bandung

Mangkunegara. 2006. Evaluasi Kinerja SDM. Refika Aditama. Bandung Alfabeta

Riduwan, dan Engkos Achmad Kuncoro. 2012. Cara Menggunakan dan Memaknai Analisis Jalur (Path Analysis). Bandung: Alfabeta

Rivai, Veitzhal dan Mukyadi, Deddy. 2012. Kepemimpinan dan Perilaku Organisasi. Jakarta: PT. Raja Grafindo Persada

Sugiyono. 2010. Metode Penelitian Kuantitatif Kualitatif \& RND. Bandung : Alfabet 
